\title{
RESSENTIMENTo E CIVILIZAÇão OCIDENTAL NA FILOSOFIA de NiETZSCHE ${ }^{1}$
}

\author{
[RESSENTIMENT'S AND WESTERN CIVILIZATION IN NIETZSCHE’S PHILOSOPHY]
}

Filipe Augusto Barreto Campello de Melo *
Universidade Federal de Pernambuco, Brasil
Isabela Gonçalves Dourado **
Universidade Federal de Pernambuco, Brasil

Resumo: Em Genealogia da moral, Nietzsche investiga a origem das valorações morais com o objetivo de denunciar as concepções metafísicas de "bem" e "mal" vigentes no Ocidente. No seu entender, esses valores seriam, na realidade, frutos de determinada procedência histórica e de perspectivas avaliadoras. E, nesse mesmo sentido, o filósofo identifica o surgimento das duplas de valores "bom e ruim" e "bom e mau", decorrentes, respectivamente, das perspectivas do "guerreiro" e do "sacerdotal". Nietzsche compreende, ainda, que tal antagonismo moral travaria uma luta milenar na história da humanidade, isso porque as perspectivas divergentes teriam configurado - em diversas sociedades e em alternados momentos - a implementação de valores equivalente a um modo de ser sadio ou doente. Ocorreria, no entanto, que um desses modos avaliativos seria predominante no processo civilizatório ocidental - e por consequência, uma dupla de valores. Assim, os valores que vigoram no Ocidente teriam procedido de uma avaliação guiada pelo pathos do "ressentimento" sentimento típico da classe "sacerdotal". Dessa maneira, a "civilização", defende Nietzsche, teria por objetivo promover uma espécie de "adestramento" humano na medida em que enfraquece os impulsos mais afirmativos e vitais dos homens e, com efeito, os direcionaria ao seu estágio mais decadente.

Palavras-chave: Nietzsche; Genealogia da moral; civilização ocidental; ressentimento; domesticação do homem
ABstract: On Genealogy of Morality, Nietzsche investigates the origin of moral evaluations in order to denounce the metaphysical conception of the notions of "good" and "evil" prevailing in the West. In his view, the values would be the result of a certain historical origin and some perspectives. It is in this sense Nietzsche identifies the emergence of the pairs of "good and bad" and "good and evil" and the perspectives of the "warrior caste" and the "priestly caste". Nietzsche also comprehends that this moral antagonism has set forth a millennial battle in the history of humanity, because those divergent perspectives would have set the implementation of values equivalents to a way of being either healthy, either sick. According to the author, the values that prevail in the West would have come from an evaluation guided by a resentment of the priestly caste. It is in this manner that the german thinker understands that the "civilization" would aim to promote a kind of human "dressage" by weakening men's most affirmative and vital impulses and, in effect, directing them to their most decadent stage.

KEYWORDS: Nietzsche; western civilization; ressentiment; domestication of man; Genealogy of morality 


\section{O DUPLO NASCIMENTO DA MORAL NO OCIDENTE}

- $\mathrm{m}$ Genealogia da moral, Friedrich Nietzsche busca pela origem dos valores morais fazendo uso de uma nova exigência: o procedimento genealógico ${ }^{2}$. O seu objetivo primeiro consiste em identificar, por meio de um exame histórico e etimológico, as condições e circunstâncias que teriam engendrado os juízos de "bem" e "mal" - tais como são concebidos na civilização ocidental. Ao pressupor a criação dos valores, nota-se que o filósofo do martelo estaria promovendo uma ruptura com uma tradição até então hegemônica no Ocidente. Nesse sentido, as noções de "bem" e "mal", defende, não deveriam mais ser entendidas no âmbito metafísico, isto é, como essenciais, imutáveis e eternas. A seu ver, elas seriam frutos de uma procedência histórica e de uma perspectiva avaliadora ${ }^{3}-$ e, por essa razão, se relevam demasiado humanas. Conforme a filosofia nietzschiana, portanto, os valores que norteiam um pensamento moral são, tão somente, decorrentes de pontos de vistas humanos inseridos em determinado contexto histórico, removendo assim, a sua legitimidade num mundo supra-sensível.

Enunciemo-la, esta nova exigência: necessitamos de uma crítica dos valores morais, o próprio valor desses valores deverá ser colocado em questão - para isto é necessário um conhecimento das $\mathrm{i}$ sob as quais se desenvolveram e se modificaram [...]. (NIETZSCHE, 2015, p. 12. Grifo nosso.)

O procedimento genealógico, no entanto, não se restringe ao mero exame histórico acerca da procedência dos valores morais. Isto é, uma vez que Nietzsche se interroga acerca do valor que esses mesmos valores teriam para o povo que os inventou, o filósofo alemão deixa clara a necessidade de se investigar também que perspectiva avaliadora ter-lhes-ia dado origem ${ }^{4}$. Ou seja, o exame histórico dos valores consistiria, na verdade, numa espécie de ferramenta para levar a cabo a avaliação dos valores e, dessa maneira, revelar o "tipo" de homem ${ }^{5}$ que os engendrou. Para efetuar essa avaliação, contudo, Nietzsche necessitou transcender a própria esfera moral. Com efeito, foi no léxico da Fisiologia e das Ciências Naturais ${ }^{6}$ que o pensador alemão encontrou um novo critério para avaliar os valores morais.

Nesses termos, o autor irá defender que a moral vigente numa época deve ser compreendida, sobretudo, como uma espécie de "sintoma" de vitalidade ou debilidade de seu povo inventor e, por conseguinte, os juízos de valor desvelariam, sob o exame genealógico, as condições de saúde a partir das quais eles mesmos foram engendrados. Ora, mas o que significaria, para Nietzsche, "saúde" e "doença" e de que maneira a moral de determinada época poderia expressar esses diferentes estados fisiológicos? Saúde, no contexto do pensamento nietzschiano, consiste na mais alta forma de afirmação da vida, enquanto que doença, ao contrario, significa vivê-la de maneira depreciadora e subestimada - e até mesmo negá-la. Tendo isso em mente, o filósofo alemão irá propor que os valores que expressam uma postura afirmativa frente à vida revelam, já em sua gênese, uma constituição fisiologicamente saudável daqueles que os criaram. Por outro lado, os valores que expressam uma atitude de negligência e negação da vida evidenciariam a própria doença como sua fonte geratriz.

A partir disso, o filósofo se propõe a diagnosticar a saúde dos povos que engendram os valores morais no Ocidente e, ao se questionar a cerca de tais valores e do modo como são concebidos numa sociedade, estes apresentar-se-iam, portanto, enquanto indícios de afirmação ou de degeneração da vida: 
do homem? São indícios de miséria, empobrecimento, degeneração da vida? Ou, ao contrário, revela-se neles a plenitude, a força, a vontade de vida, sua coragem, sua certeza, seu futuro? (NIETZSCHE, 2015, p. 9)

A partir desse questionamento, Nietzsche identifica a existência de pelo menos duas perspectivas avaliativas que, na história das civilizações, teriam gerado, respectivamente, dois pares de valores com sentidos totalmente distintos entre si: de um lado, teríamos a dupla de valores "bom" e "ruim" (gut/schecht) e, de outro lado, "bom" e "mau" (gut/böse). É desse modo, portanto, que o filósofo alemão lança a sua hipótese acerca do duplo nascimento da moral no Ocidente", a saber, a "moral do homem forte" e a "moral do homem fraco".

\subsection{A MORAL DO HOMEM FORTE: O MODO GUERREIRO-ARISTOCRATA DE VALORAR}

Conforme a exigência genealógica, Nietzsche defende que a primeira perspectiva avaliadora teria sido desenvolvida por um tipo de homem nobre-aristocrata. Isso porque, no seu entender, o elemento denotador da criação dos juízos se encontraria numa espécie de sentimento típico da nobreza, o que ele chama de pathos de distância ${ }^{8}$. Tal disposição afetiva permitiria que toda estirpe senhorial se sentisse em posição mais elevada em relação a outras castas e também que a essa distinção fosse defendida por meio de relações hierárquicas de poder. É nesse sentido que, defende o autor, esses homens de assumido instinto de superioridade criaram os valores a partir de um movimento de "autoafirmação". Ora, sob esse ponto de vista, tudo aquilo que se encontra relacionado aos próprios homens nobres ${ }^{9}$ e aos seus atos seria designado como "bom" e, apenas como consequência disso - ou seja, posteriormente -, estes senhores passaram a julgar o diferente de si, isto é, o homem comum e plebeu, como o seu oposto. É desse modo, portanto, que os nobres-aristocratas criaram para si o juízo de valor "ruim" como uma espécie de antítese a sua própria casta e seu modo de ser.

Foram os "bons" mesmos, isto é, os nobres, poderosos, superiores em posição e pensamento, que sentiram e estabeleceram a si e a seus atos como bons, ou seja, de primeira ordem, em oposição a tudo que era baixo, de pensamento baixo, e vulgar e plebeu. (NIETZSCHE, 2015, p. 16-17. Grifo nosso.)

Fazendo uso da etimologia, Nietzsche observa, ainda, que as designações linguísticas para algo tido como "bom", em diversos idiomas ${ }^{10}$, remetem sempre à mesma matriz etimológica que, em última instância, derivariam de termos que invariavelmente se referem à noção de nobreza ${ }^{11}$. Em paralelo a isso, ocorreria que tudo que indica oposição ao que é nobre, ou seja, o que é baixo e vulgar, teria parentesco semântico 12 com a noção de "ruim".

[...] em toda parte, "nobre", "aristocrático", no sentido social, é o conceito básico a partir do qual necessariamente se desenvolveu "bom", no sentido de "espiritualmente nobre" [...], um desenvolvimento que sempre corre em paralelo àquele outro que faz "plebeu", "comum", "baixo" transmutar-se finalmente em "ruim". [...] O exemplo mais eloquente deste último é o próprio termo alemão schlecht [ruim] o qual é idêntico a schlicht [simples]. (NIETZSCHE, 2015, p. 18)

Seguindo a esse raciocínio, nos primórdios das civilizações, cada acontecimento teria sido avaliado e apropriado pelo ponto de vista das castas dominantes. Assim, "bom", entre os nobres-aristocratas, designaria tudo aquilo que exalta as prerrogativas 
da aristocracia e a distingue do restante das massas. Adotando como paradigma as aristocracias guerreiras da Antiguidade ${ }^{13}$, sobretudo, da Grécia homérica, Nietzsche ressalta, ainda, que uma "boa constituição física" compreende o modo de ser característico desse tipo de homem. Em outros termos, ele defende que as atividades mais robustas e violentas, como a caça, a guerra, a perseguição do diferente evidenciam e conservam o homem nobre em sua saúde exuberante.

Os juízos de valor cavalheiresco-aristocráticos têm como pressuposto uma constituição física poderosa, uma saúde florescente, rica, até mesmo transbordante, juntamente com aquilo que serve à sua conservação: guerra, aventura, caça, dança, torneios e tudo que envolve uma atividade robusta, livre e contente. (NIETZSCHE, 2015, p. 22)

A perspectiva guerreira-aristocrata, portanto, promove valores que brotam de um modo de vida ascendente, que, conforme Nietzsche, seria próprio dos indivíduos mais fortes e mais ativos. Sob a perspectiva sintomatológica nietzschiana, o modo de valorar da casta nobre evidenciaria um tipo de vida mais sadio, pois saúde seria, justamente, a expressão livre e espontânea da vitalidade constituintes dos corpos de indivíduos vivos. De antemão, é preciso termos em mente que, neste contexto, o filósofo adota a noção de Vontade de Potência ${ }^{14}$ como referencial argumentativo de sua hipótese acerca da saúde e da doença. De uma maneira bem breve, poderíamos definir a noção nietzschiana de Vontade de Potência como uma espécie de querer impulsivo por mais domínio e poder. Para o autor de Assim falava Zaratustra, todo ser vivente ${ }^{15}$ seria constituído por um constante anseio de subjugação e apropriação do alheio. Conforme o critério fisiológico nietzschiano, um indivíduo tipicamente saudável seria aquele que busca efetivar livremente os seus impulsos violentos característicos, deixando entender que, de tal forma, haveria uma relação direta entre a afirmação da vida imanente e a livre expressão de suas forças mais espontâneas. Do modo contrário, portanto, aquele que tende a inibir ou retrair as suas próprias forças vitais caracterizar-se-ia como um individuo doente.

\subsection{A MORAL DO HOMEM FRACO: O MODO SACERDOTAL DE VALORAR}

Ainda tendo em mente o contexto da Vontade de potência, Nietzsche identifica que outro modo de valorar teria surgido no Ocidente. Isto é, uma nova concepção acerca dos valores ganharia forma através de uma perspectiva avaliadora distinta da nobre-aristocrata, a saber, a perspectiva nobre-sacerdotal. Para o autor de Genealogia da moral, também os sacerdotes - homens pertencentes à nobreza, no entanto, providos de uma vitalidade decadente - teriam concebido valores e instaurado uma moralidade a partir do seu próprio modo de ser, este, caracterizado pela fraqueza, impotência e desvalorização da vida imanente.

Já se percebe com que facilidade o modo de valoração sacerdotal pode derivar daquele cavalheiresco-aristocrático e depois desenvolver-se em seu oposto; em especial, isso ocorre quando a casta dos sacerdotes e a dos guerreiros se confrontam ciumentamente, e não entram em acordo quanto às suas estimativas. Os juízos de valor cavalheiresco-aristocráticos têm como pressuposto uma constituição física poderosa, uma saúde florescente [...] $\mathrm{O}$ modo de valoração nobre-sacerdotal -[...] tem outros pressupostos: para ele a guerra é mau negócio! (NIETZSCHE, 2015, p. 22-23)

Quando confrontada com a classe dos nobres-guerreiros, a casta nobre- 
sacerdotal teria, sido tomada pelo pathos de ressentimento, isto é, um estado de espírito caracterizado pelo sentimento de ódio e de invídia em relação à aristocracia guerreira. Assim, Nietzsche argumenta que a disposição afetiva do ressentimento consistiria na matéria-prima a partir da qual se engendrariam as noções de "bom" e "mau" que norteiam a moral dos sacerdotes. Tais valores seriam, dessa maneira, frutos de uma condição de fraqueza e de incapacidade dos sacerdotes em revidar ou expressar a sua indignação de maneira direta e imediata, caracterizando-se numa tentativa de vingança dos homens fracos em relação aos mais fortes. ${ }^{16}$

Com os sacerdotes tudo se torna mais perigoso, não apenas meios de cura e artes médicas, mas também altivez, vingança, perspicácia, dissolução, amor, sede de domínio, virtude, doença - mas com alguma equidade se acrescentaria que somente no âmbito dessa forma essencialmente perigosa de existência humana, a sacerdotal, é que o homem se tornou um animal interessante, apenas então a alma humana ganhou profundidade num sentido superior, e tornou-se má [...]. (NIETZSCHE, 2015, p. 22. Grifo nosso.)

Nietzsche sublinha, além disso, que a moralidade guiada pelo pathos de ressentimento teria sido popularizada pelos sacerdotes e recebido ampla aderência na casta dos homens mais oprimidos e fracos, os quais o autor designa pelo termo genérico "escravos". Dessa maneira, os homens do ressentimento, defende o pensador, teriam elaborado uma espécie de subterfúgio cujo principal objetivo seria impelir uma "vingança imaginária" na qual os escravos, por fim, se voltariam contra os senhores: "O próprio ressentimento se torna criador e gera valores: o ressentimento dos seres aos quais é negada a verdadeira reação, a dos atos, e que apenas por uma vingança imaginária obtêm reparação". (NIETZSCHE, 2015, p. 26). Em outras palavras, como os escravos não possuíam, por princípio, força e poder suficientes para promover um combate corpóreo direto e imediato contra os senhores que os oprimiam, sua reação estratégica consistiu em nomear o seu adversário, o homem forte, como o "inimigo mau" e, a partir disso, configurar a si mesmo como sua antítese, isto é, um homem "bom". 17

Tendo em mente esse cenário, é possível concluirmos que os valores nobressacerdotais não teriam surgido a partir de um ato criador expontâneo, como ocorreria com os valores guerreiros-aristocratas. As noções de "bom" e de "mau", próprias do tipo decadente, argumenta Nietzsche, teriam a sua origem numa reação aos valores primários "bom" e "ruim", instituídos, como visto, pelo tipo forte.

[...] já de início a moral escrava diz Não a um "fora", um "outro", um "não-eu" e este Não é seu ato criador. Esta inversão do olhar que estabelece valores - este necessário dirigir-se para fora, em vez de voltar-se para si é algo próprio do ressentimento: a moral escrava sempre requer, para nascer, um mundo oposto e exterior, para poder agir em absoluto - sua ação é no fundo reação. (NIETZSCHE, 2015, p. 26)

Tendo por base suas investigações genealógicas acerca da moralidade, Nietzsche compreende que teria ocorrido, na história da moral ocidental, uma subversão dos valores guerreiro-aristocratas em detrimento dos valores nobre-sacerdotais. Ou seja: enquanto que, num primeiro momento, a noção de "bom" se referia sempre aos mais fortes, mais potentes, nobres e guerreiros como um ato de autoafirmação, posteriormente, com a transvaloração valorativa escrava-sacerdotal, o "bom" passaria a designar todo aquele que se identifica como o tipo fraco. A esse respeito, o pensador alemão irá ressaltar que essa subversão passou a ganhar força, sobretudo, graças à adesão dos povos mais oprimidos das castas dos escravos à moral sacerdotal. É nesse 
sentido que o filósofo do martelo identifica na figura do o povo judeu - considerando, de antemão, o seu contexto histórico de opressão e perseguição - a chave para compreensão da reviravolta moral no Ocidente. ${ }^{18}$

Foram os judeus que, com apavorante coerência, ousaram inverter a equação de valores aristocrática $($ bom $=$ nobre $=$ poderoso $=$ belo $=$ feliz $=$ caro aos deuses), $\mathrm{e}$ com unhas e dentes (os dentes do ódio mais fundo, o ódio impotente) se apegaram a esta inversão, a saber, "os miseráveis somente são os bons, apenas os pobres, impotentes, baixos são bons, os sofredores, necessitados, feios, doentes são os únicos beatos, os únicos abençoados, unicamente para eles há bem-aventurança mas vocês, nobres e poderosos, vocês serão por toda a eternidade os maus, os cruéis, os lascivos, os insaciáveis, os ímpios, serão também eternamente os desventurados, malditos e danados!...”. (NIETZSCHE, 2015, p. 23. Grifo nosso.)

Em resumo, a proposta da inversão valorativa escrava-sacerdotal teria como objetivo central converter o valor "bom" da moral nobre-aristocrata num sentido equivalente a fraco, comum, humilde, enfermo, vil e impotente, ou seja, o valor "ruim" dessa mesma moral. Em decorrência da recusa do modo de valorar guerreiroaristocrata, os sacerdotes e os escravos teriam promovido uma "moralidade ressentida" de negação dos valores tipicamente nobres, isto é, de valores que promovem e incitam a afirmação da vida e do corpo em suas expressões mais exuberantes e vitais. Para Nietzsche, do ponto de vista fisiológico, a perspectiva escravo-sacerdotal se revelaria como uma espécie de sintoma de vidas adoecidas e decadentes.

\section{RESSENTIMENTO E CIVILIZAÇÃO OCIDENTAL}

\section{$2.1 O$ cristianismo na civilização ocidental}

Ao examinar a dupla procedência dos valores morais, Nietzsche identifica que uma das perspectivas avaliadoras das quais expomos seria predominante no Ocidente. A seu ver, os valores reconfigurados e implantados pelo tipo fraco - isto é os sacerdotes e os escravos - obtiveram êxito na história dessa civilização. No contexto da Genealogia da moral, o pensador alemão argumenta que os juízos de "bom" e "mau" teriam se sustentado, ao longo das épocas, sobretudo devido à popularização dos ideais morais judaico-cristãos. Fazendo uso de uma hipótese histórica, o filósofo passa a compreender que a moral judaica teria, por fim, predominado na civilização ocidental, colocando em evidência, de tal maneira, um modo de ser caracterizado, principalmente, pelo pathos de ressentimento. Assim, o sacerdote judeu teria produzido - por meio de uma inversão dos valores nobres originários - uma moral que, acima de tudo, ansiava uma revanche divina contra os fortes. É nesse sentido que, argumenta Nietzsche, facilmente essa moral obteve aderência dos povos mais oprimidos e escravizados.

- "Mas que quer ainda você com ideais mais nobres! Sujeitemo-nos aos fatos: o povo venceu - ou 'os escravos', ou 'a plebe', ou 'o rebanho', ou como quiser chamá-lo - se isto aconteceu graças aos judeus, muito bem! jamais um povo teve missão maior na história universal. 'Os senhores' foram abolidos; a moral do homem comum venceu. [...]. (NIETZSCHE, 2015, p. 25)

Tendo em mente esse cenário, a própria doutrina cristã - considerada como o principal pilar da moral no Ocidente - consistiria numa espécie de prolongamento ${ }^{19}$ do ódio e da vontade de vingança estimulados pela inversão valorativa dos sacerdotes e do 
povo judeu. Por essa razão, no entender de Nietzsche, tanto o judaísmo quanto o cristianismo teriam se configurado a partir do mesmo pathos de ressentimento, pois seus povos teriam um histórico análogo de opressão e escravidão. Isso significaria dizer, portanto, que a doutrina cristã operaria moralmente a partir de uma perspectiva avaliadora semelhante à do homem fraco, isto é, invertendo o ponto de vista nobre a fim de recriar os valores de uma moral da qual seria, por fim, agraciado, enquanto que o seu opressor seria visto de modo inferiorizado.

Do tronco daquela árvore da vingança e do ódio judeu - o mais profundo e sublime, o ódio criado de ideias e recriador de valores, como jamais existiu na terra -, dele brotou algo igualmente incomparável, um novo amor [...]. Mas não se pense que tenha surgido como a negação daquela avidez de vingança, como antítese do ódio judeu! Não, o contrário é a verdade! (NIETZSCHE, 2015, p. 24. Grifo nosso.)

Contudo, ocorreria no Cristianismo o uso de uma estratégia ainda mais radical que a do sacerdote judeu, utilizada para legitimar e por em evidência a inversão dos valores da moral dos homens fracos. Fundamentada sobre as noções de "mundo-Além" e "Juízo final", a doutrina cristã, argumenta o filósofo alemão, teria "forjado" a ideia de uma justiça divina que promoveria a vingança de todo sofrimento terreno de um "povo eleito por Deus".

Fé em quê? Amor a quê? Esperança de quê? - Esses fracos - também eles desejam ser os fortes algum dia, não há dúvida, também o seu "reino" deverá vir algum dia - chamam-no simplesmente "o Reino de Deus", como vimos: são mesmo tão humildes em tudo! Para vivenciar isto é preciso viver uma vida longa, que ultrapasse a morte - é preciso a vida eterna para ser eternamente recompensado no "Reino de Deus" por essa existência terrena "no amor, na fé, na esperança”. (NIETZSCHE, 2015, p. 36)

Nesse sentido, toda opressão sofrida durante a vida imanente seria convertida, aos bem-aventurados - portanto, os homens fracos, escravos e oprimidos -, numa espécie de recompensa transcendente. Do mesmo modo, os homens "maus" - isto é, os senhores, os mais fortes e mais potentes - receberiam castigos eternos decorrentes de suas "maldades" cometidas contra esses povos oprimidos na vida terrena. Em outras palavras, para Nietzsche a esperança de uma "vida eterna" num "mundo-Além" se constituiria, na realidade, como um artifício da moral cristã que funcionaria, primeiro, para justificar a impotência dos mais beatos, dando-lhes o consolo de uma revanche contra os homens "maus", e, segundo, para promover, a partir do medo de um castigo eterno, o respeito e a obediência aos seus princípios. Nesse sentido, a "inversão do olhar" gerada pelo tipo fraco se consolidaria, ainda mais, a partir da conversão de toda fraqueza em virtude a ser recompensada no além-túmulo:

A fraqueza é mentirosamente mudada em mérito [...] e a impotência que não
acerta contas é mudada em 'bondade'; a baixeza medrosa, em 'humildade'; a
submissão àqueles que se odeia em 'obediência' [...] O que há de inofensivo no
fraco, a própria covardia na qual é prodigo [...], recebe aqui o bom nome de
'paciência' [...] não-poder-vingar-se chama-se não-querer-vingar-se, talvez
mesmo perdão (pois eles não sabem o que fazem [...] E como chamam aquilo que
lhes serve de consolo por todo sofrimento da vida? - sua fantasmagoria da bem-
aventurança futura antecipada? [...] a isso chamam de 'Juízo final', o advento do
seu reino, do 'Reino de Deus'. (NIETZSCHE, 2015, p. 34-35)

No contexto da filosofia nietzschiana, a inversão escrava-sacerdotal teria causado impactos efetivos na civilização ocidental. ${ }^{20}$ Ora, uma vez que, conforme a 
perspectiva supracitada, as adversidades da vida seriam encaradas unicamente como um meio de alcançar uma glória no "mundo-Além", a doutrina cristã estaria dando suprimento a um tipo de pensamento moral que teria como consequências o enfraquecimento dos impulsos humanos mais vitais em função da mortificação do corpo e, portanto, a negação da própria vida. ${ }^{21}$

\subsection{CiVILIZAÇÃo OCIDENTAL, RESSENTIMENTO E ADESTRAMENTO DO HOMEM}

Nietzsche compreende que o antagonismo entre as duplas de valores "bom e ruim" e "bom e mau" travaram uma luta milenar na história da humanidade. No entender do autor, o confronto entre as perspectivas nobre-guerreira e escravasacerdotal teria configurado, em diferentes momentos, a implementação de valores equivalentes a modos de ser divergentes: ser ora sadio, ora doente. No contexto da Genealogia da moral, ocorre que um desses tipos de avaliação valorativa teria predominado no Ocidente, a saber, a moral do homem tipicamente fraco. É nesse sentido que o filósofo alemão identifica que um dos principais pilares da moralidade ocidental se edificaria, justamente, no pathos de ressentimento e na decadência humana que caracterizam a doutrina cristã. Em termos fisiológicos, os valores que vigoram em nossa civilização - os quais teriam as suas bases solidificadas em um pensamento metafísico-religioso e, para Nietzsche, se constituiriam como valores negadores da vida terrena - teriam envenenado a humanidade, fazendo-a atingir seu estágio mais doentio e decadente uma vez que tende a estimular propositalmente o enfraquecimento dos homens. ${ }^{22}$

É nesse mesmo sentido que o pensador alemão irá defender a existência de uma íntima relação entre a moral do ressentimento e o processo civilizatório no Ocidente, isso porque, a "civilização", no seu entender, teria por objetivo a promoção do "adestramento" do bicho-homem aos moldes da perspectiva escrava-sacertotal. Isto é, o valor "bom" que por então vigora no mundo ocidental, seria equivalente ao valor "bom" do cristianismo. Nesse contexto, valoriza-se, portanto, o homem fraco, impotente, doente. Nessa condição, a moralidade ocidental coloca em prática os juízos escravo-sacerdotais e, de tal maneira, o tipo de homem fraco passaria a ser visto como superior e, dessa forma, deveria ser conservado. Isso porque ele é tido, aparentemente, como inofensivo, incapaz de fazer maldades, obediente, domado. Enfim, útil para a conservação dos valores gregários, o tipo fraco se configuraria como o "bom". O homem forte, isto é, mais potente, ativo e violento, por outro lado, seria determinado como um perigo a estes costumes e, de tal maneira, seria encarado como "mau".

Dessa maneira, tal concepção de "civilização" se configuraria como um conjunto de homens "domesticados" cujos impulsos afirmativos mais seriam totalmente enfraquecidos, amansados, redirecionamos de modo a não prejudicar a vida em comunidade. Em resumo, o próprio processo civilizatório do Ocidente, argumenta Nietzsche, teria de formado por meio da implementação e legitimação de uma moral alimentada pelo instinto do ressentimento.

Supondo que [...] o sentido de toda cultura é amestrar o animal de rapina "homem", reduzi-lo a um animal manso e civilizado, doméstico, então deveríamos sem dúvida tomar aqueles instintos de reação e ressentimento, com cujo auxílio foram finalmente liquidadas e vencidas as estirpes nobres e os seus ideais, como os autênticos instrumentos de cultura [...]. (NIETZSCHE, 2015, p. 30)

Nesse sentido, o filósofo alemão conclui que a moralidade cristã - isto é, a 
principal fonte e influência do pensamento moral no Ocidente - teria direcionado a humanidade ao seu estágio mais decadente ${ }^{23}$. Isso porque, a doutrina do Cristianismo, assim como a moral do nobre-sacerdote e do judaísmo, teria por objetivo central a promoção da vida ascética em vista de uma vida-além - visando assim, uma igualdade entre todos. No entanto, a negação de valores que enaltecem a vida corpórea e terrena no entender de Nietzsche, a única forma de vida possível - nos daria claros indícios de que a sociedade ocidental estaria fatalmente adoecida. Uma vez observado que o tipo de homem aceito nas em "sociedades civilizadas" deve respeitar, invariavelmente, às condutas impostas por uma moral ressentida, Nietzsche denuncia que a própria ideia de "civilização" consistiria num verdadeiro processo de "domesticação" humana:

Que ele [o sacerdote] tenha podido dispor e apoderar-se dos homens da maneira como a história ensina, em especial onde se impôs a civilização e domesticação do homem, nisto se expressa uma grande realidade: a condição doentia do tipo de homem até agora existente, ao menos do homem domesticado [...] O sacerdote ascético é a encarnação do desejo de ser outro, de ser-estar em outro lugar, é o mais alto grau desse desejo, sua verdadeira febre e paixão: mas precisamente o poder do seu desejo é o grilhão que o prende aqui; precisamente por isso ele se torna o instrumento que deve trabalhar para a criação de condições mais propícias para o ser-aqui e o ser-homem - precisamente com este poder ele mantém apegado à vida todo o rebanho de malogrados, desgraçados, frustrados, deformados, sofredores de toda espécie, ao colocar-se instintivamente à sua frente como pastor. Já me entendem: este sacerdote ascético, este aparente inimigo da vida, este negador [...] (NIETZSCHE, 2015, p. 101-102).

Tendo em mente o argumento genealógico acerca do processo de civilização, poderíamos concluir que o trabalho do sacerdote de promover uma vida ascética teria ganhado força e aprovação no processo civilizatório das sociedades ocidentais, isso porque ambos baseiam-se no nivelamento e na domesticação dos homens. Uma civilização pautada em valores transcendentes, os quais visam "amansar" os instintos vitais dos homens se configuraria, defende Nietzsche, num conjunto de indivíduos negadores da própria vida, e, por essa razão, evidenciam-se como sintomas de um povo mórbido, adoecido e decadente.

\section{REFERÊNCIAS:}

ITAPARICA, André L. M. Notas sobre a naturalização da moral em Nietzsche. In: PASCHAL, Edmilson e FREZZATTI, Wilson (orgs). 120 anos de "Para a genealogia da moral". Ijuí: Unijuí, 2008.

MARTON, Scarlett. Das forças cósmicas aos valores humanos. Belo Horizonte: Editora UFMG, 2010.

MARTON, Scarlett. Extravagâncias: ensaios sobre a Filosofia de Nietzsche. São Paulo: Discurso Editorial e Editora Uniluí, 2001.

MARTON, Scarlett. Nietzsche: a transvaloração dos valores. São Paulo: Editora Moderna, 2006.

NIETZSCHE, Friedrich. Além de bem e mal. Trad. Paulo César de Sousa. São Paulo: Companhia das Letras, 2005. (Companhia de bolso).

NIETZSCHE, Friedrich. Genealogia da moral. Trad. Paulo César de Sousa. São Paulo: Companhia das Letras, 2015. (Companhia de bolso).

NIETZSCHE, Friedrich. O Anticristo. Trad. Paulo César de Souza. São Paulo: Companhia das Letras, 2006.

\section{Notas}


$1 \mathrm{O}$ presente texto é resultado da reformulação de uma comunicação apresentada na "I Jornada Nietzsche", em fevereiro de 2019, na Universidade Federal Rural de Pernambuco, em Recife.

2 O procedimento genealógico consiste numa espécie de "método" utilizado por Nietzsche com o objetivo de investigar a proveniência histórica dos valores morais vigentes na civilização ocidental. Essa investigação revela que todos os valores seriam engendrados a partir de perspectivas valorativas, contrapondo-se, dessa maneira, a qualquer especulação metafísica que tende a compreender os valores morais como existindo desde sempre. Com esse "método", o filósofo alemão pretende colocar em questão o próprio "valor dos valores" na medida em que identifica as condições históricas e circunstâncias gerais dos povos que os inventaram. Sobre o procedimento genealógico de Nietzsche, conferir o capítulo II de "Das forças cósmicas aos valores humanos" de Marton.

3 A esse respeito, conferir o comentário de Marton: "Se os valores de 'bem' e 'mal' não foram colocados em questão, é porque eles foram vistos como existindo desde sempre: instituídos num além, encontravam legitimidade num mundo supra-sensível. No entanto, uma vez questionados, revelam-se apenas 'humanos, demasiado humanos'[...]". (MARTON, 2010, p. 79).

4 "[...] a questão do valor apresenta duplo caráter: os valores supõem avaliações, que lhes dão origem e conferem valor; estas, por sua vez, ao criá-los, supõem valores a partir dos quais avaliam." (MARTON, 2010, p. 72).

5 É importante ressaltar que Nietzsche pretende diagnosticar as condições de saúde da civilização ocidental - tendo em mente a própria vida como um critério avaliativo - e não delimitar uma espécie de essencialidade que constitui os povos de determinada sociedade ou cultura. A respeito disso, conferir o comentário da professora Scarlett Marton: "[...] fortes e fracos, nobres e ressentidos, senhores e escravos não constituem um a priori metafísico nem essências atemporais; são tipos que emergem da pesquisa histórica”. (MARTON, 2006, p. 60).

6 Em sua análise genealógica, Nietzsche põe a seu serviço, além da História, uma linguagem muito próxima às Ciências Naturais e da medicina. Debruçando-se sobre teses da Fisiologia de sua época, o filósofo lança mão de uma estratégia argumentativa que faz uso de um referencial científico como um instrumento para por à prova sua hipótese interpretativa - nesse caso, sobre a origem dos valores morais no Ocidente -, não se caracterizando, de modo algum, como um método propriamente científico. Portanto, neste contexto, Nietzsche não poderia ser interpretado como uma espécie de cientista que teria a pretensão positivista de apresentar um relato histórico nem mesmo científico acerca do mundo ou das relações humanas. A esse respeito, Cf. ITAPARICA, 2008, p. 33.

7 Sobre o duplo nascimento da moral, conferir também Além de bem e mal: "Encontrei certos traços retornando juntos regularmente e ligados um ao outro; até que, por fim, dois tipos fundamentais se denunciaram a mim, e ressaltou uma diferença fundamental. Há moral de senhores e moral de escravos: acrescento desde logo que, em todas as civilizações superiores e mais mistas, entram também em cena ensaios de mediação entre ambas as morais, e ainda mais frequentemente a mescla de ambas e recíproco mal entendido, e até mesmo, às vezes, seu duro lado a lado - até no mesmo homem, no interior de uma única alma" (NIETZSCHE, 2005, p. 123).

8 Nietzsche faz uso do termo "pathos de distância" ou mesmo "sentimento de distância" para descrever uma disposição afetiva própria de um tipo de homem que fomenta a criação dos valores entre as castas mais nobres e dominantes - o homem forte. Nesse contexto, o movimento de autoafirmação e autorreconhecimento frente às demais castas constituiriam o ato fundador de toda moral nobre-aristocrata: "O pathos da nobreza e da distância, como já disse, o duradouro, dominante sentimento global de uma elevada estirpe senhorial, em sua relação com uma estirpe baixa, com um "sob" - eis a origem da oposição ‘bom' e 'ruim'”. (NIETZSCHE, 2015, p. 17).

9 A nobreza a qual Nietzsche se refere pode ser identificada em diferentes períodos da história do Ocidente, se expressando, inclusive, nas figuras da aristocracia guerreira da Grécia antiga, em Heráclito de Éfeso, na classe guerreira de Roma, em Napoleão, dentre outros. A 
respeito dos homens nobres, cf. MARTON, 2001, p. 193.

10 No contexto da genealogia, o filósofo recorre não apenas ao alemão, mas, sobretudo ao grego e ao latim para por à prova a sua hipótese genealógica e fisiológica. A respeito disso, conferir as seções $\$ 5$ e $\S 10$ da primeira dissertação da Genealogia da moral (NIETZSCHE 2015, p. 19-21 e 26-28).

11 "em toda parte, 'nobre', 'aristocrático', no sentido social, é o conceito básico a partir do qual necessariamente se desenvolveu 'bom', no sentido de 'espiritualmente privilegiado'." (NIETZSCHE, 2015, p. 18).

12 Nietzsche irá defender, portanto, que, em sua gênese, as palavras "bom" e "ruim" designavam a maneira como a classe nobre-aristocrata se autorreconhecia e procurava se distinguir das demais classes e povos. De tal maneira, o termo "bom" desvelaria também um "traço típico do caráter" daqueles que estabelecem os valores. "[...] nas palavras e raízes das palavras que designam o "bom", transparece ainda a nuance cardeal pela qual os nobres se sentiam homens de categoria superior. É verdade que, talvez na maioria dos casos, eles designam a si mesmos conforme simplesmente a sua superioridade no poder [...] "os poderosos", "os senhores", “os possuidores" [...]". (NIETZCHE, 2015, p. 19)

13 Nietzsche tem como referencial a época da Grécia Clássica agonística, no entanto, ele reconhece a presença das raças dominantes em diversos contextos históricos a partir do termo genérico "bestas louras": "Na raiz de todas as raças nobres é difícil não reconhecer o animal de rapina, a magnífica besta loura que vagueia ávida de espólio e vitórias; de quando em quando este cerne oculto necessita de desafogo, o animal tem que sair fora, tem que voltar à selva - nobreza romana, árabe, germânica, japonesa, heróis homéricos, vikings escandinavos: nessa necessidade se assemelham". (NIETZSCHE, 2015, p. 29).

14 Sobre essa noção nietzschiana conferir o capítulo I de "Das forças cósmicas aos valores humanos" de Marton.

15 "Onde encontrei vida, ali encontrei vontade de potência [...]" (NIETZSCHE, 2014, p. 245).

16 Os sacerdotes são, como sabemos, os mais terríveis inimigos - por quê? Porque são os mais impotentes. Na sua impotência, o ódio toma proporções monstruosas e sinistras, torna-se a coisa mais espiritual e venenosa. (NIETZSCHE, 2015, p. 23).

17 “[...] ele concebeu o 'inimigo mau', o 'mau', e isto como conceito básico, a partir do qual também elabora, como imagem equivalente, um 'bom' - ele mesmo!’(NIETZSCHE, 2015, p. 28).

18 "A história humana seria uma tolice, sem o espírito que os impotentes the trouxeram tomemos logo o exemplo maior. Nada do que na terra se fez contra 'os nobres', 'os poderosos', 'os senhores', 'os donos do poder', é remotamente comparável ao que os judeus contra eles fizeram; os judeus, aquele povo de sacerdotes que soube desforrar-se de seus inimigos e conquistadores apenas através de uma radical (sic) tresvaloração dos valores deles, ou seja, por um ato da mais espiritual vingança." (NIETZSCHE, 2015, p. 23).

19 Nietzsche defende que a doutrina cristã teria legitimado e popularizado as ideias de mundoAlém e Juizo Final já presentes na tradição judaica. Nesse sentido, o Cristianismo teria apenas dado continuidade ao pensamento moral ressentido concretizado no Judaísmo. A respeito disso, conferir a seção $\$ 27$ de $O$ Anticristo.

20 "A própria humanidade sofre ainda os efeitos dessas veleidades de cura sacerdotais!" (NIETZSCHE, 2015, p. 21).

21 "Para poder dizer Não a tudo o que constitui o movimento ascendente da vida, a tudo que na Terra vingou, o poder, a beleza, a auto-afirmação, o instinto do ressentimento, aqui tornado gênio, teve de inventar um outro mundo, a partir do qual a afirmação da vida apareceu como o mau, como o condenável em si." (NIETZSCHE, 2007, p. 29. Grifo nosso.).

22 Sobre o processo de civilização como "melhorado" do homem, Nietzsche nos diria: "[...] para mim, 'melhorado' significa - o mesmo que 'domesticado', ‘enfraquecido', 'desencorajado', 'refinado' [...] (ou seja, quase o mesmo que lesado). Mas tratando-se sobretudo de doentes, desgraçados, deprimidos, um tal sistema torna o doente invariavelmente mais doente, ainda que o torne 'melhor' [...]." (NIETZSCHE, 2007, p. 
122.)

23 Ao se tratar do modo de vida decadente, Nietzsche acusa, sem sombra de dúvidas, a moral judaico-cristã como seu principal provedor. No entanto, é necessário ter em mente que o autor também presta as devidas referências ao platonismo. No seu entender, haveria uma íntima ligação entre platonismo e cristianismo, isso porque, a filosofia de Platão serviria de fundamento para a implementação de um pensamento ético-metafísica na moral cristã. A noção de um "mundo supra-sensível" em detrimento de um "mundo sensível", por exemplo, serviria de base retórica para a legitimação de ideais a partir dos quais fizeram erigir toda moral de negação da vida. Nas palavras do autor: "o cristianismo é o platonismo para o povo". (NIETZSCHE, 2005, p. 8) 